\title{
Hubungan Patron Klien pada Masyarakat Tani Marayoka di Jeneponto 1970-2018
}

\author{
Ramidha. M, Ahmadin, Jumadi \\ Prodi Pendidikan Sejarah Fakultas Ilmu Sosial Universitas Negeri Makassar \\ ramidha22@gmail.com
}

\begin{abstract}
Abstrak
Penelitian ini bertujuan untuk mengetahui kehidupan masyarakat tani sebelum adanya sistem pengupahan antara patron dan klien kemudian terjadi pengupahan hingga pergeseran atau peningkatan ekonomi seorang patron ataupun klien, dampak dari hubungan patron-klien bagi kehidupan masyarakat tani pada bidang sosial-budaya dan ekonomi di Marayoka (1970-2018). Hasil penelitian ini menunjukan bahwa sebelum adanya sistem pengupahan antara patron dan klien di Desa Marayoka, pertanian masih bersifat subsisten, dimana masyarakat hanya bekerja seadanya untuk memenuhi kehidupan sehari-hari dan mereka masih sangat tunduk dan patuh kepada patron tanpa mendapatkan upah (sukarela), adanya sistem pengupahan masyarakat sudah mulai mencari kehidupan sendiri, kehidupan masyarakat tani di Desa Marayoka mulai mengalami peningkatan terutama dari segi ekonominya. Selain itu juga memberi dampak terhadap sistem mata pencaharian masyarakat setempat. Komoditi utama yang diusahakan jagung kuning, dan tanaman palawijaya, Namun belakangan ini usaha menjadi menurun. Bahkan sebagaian petani ada yang mengeluh karena kebun jagung dan padi produksinya menurun dan pendapatan rendah. Dari penelitian ini dapat ditarik kesimpulan bahwa sebelum adanya sistem pengupahan masyarakat marayoka masih terjaling erat kerjasama misalkan pengerjaan lahan milik yang secara bergilirang tanpa terimah upah kemudian membangun hubungan patron-client dengan buruh tani melalui penggunaan buruh langganan dan buruh tetap agar tidak terjadi kecurangan.
\end{abstract}

\section{Kata Kunci: Patron, Upah, Marayoka}

\begin{abstract}
This study aims to determine the life of the farmer community before the wage system exists between patrons and clients and the occurrence of wages to shift or increase the economy of a patron or client, the impact of the patron-client relationship for the life of the farming community in the socio-cultural and economic fields in Marayoka (1970 -2018). The results of this study indicate that before the wage system exists between patrons and clients in Marayoka Village, agriculture is still subsistence, where people only work poorly to fulfill their daily lives and they are still very submissive and obedient to patrons without getting paid (voluntary), the community wage system has begun to look for its own life, the life of the farming community in Marayoka Village has begun to increase, especially in terms of its economy. It also has an impact on the local people's livelihood systems. From this study, it can be concluded that before the marayoka community wage system was still closely intertwined with the cooperation, for example, the work of land owned by the recipient without wages then built a patron-client relationship with farm laborers through the use of subscribed and permanent laborers to avoid fraud.
\end{abstract}

\section{Keywords: Patron, Wage, Marayoka}




\section{A. Pendahuluan}

Pembangunan pertanian diarahkan untuk meningkatkan produksi pertanian guna memenuhi kebutuhan pangan dan kebutuhan industri dalam negeri, meningkatkan ekspor, meningkatkan pendapatan petani, memperluas kesempatan kerja dan mendorong. Hubungan patron klien dikalangan orang bugis dapat kita temukan pada hubungan yang terjadi antara sesorang yang disebut dengan ajjoareng dengan joa'. Ajjoareng adalah seorang yang menjadi ikutan atau panutan. dia ini bisa seorang punggawa, aru, karaeng ataupun pemuka masyarakat lainnya. Pendeknya dia merupakan toko pemimpin yang menjadi pusat atau poros kegiatan orang-orang disekitaranya yang kemauan dan kehendaknya diikuti dan patuh oleh mereka ini, yang merupakan pengikut setianya. Pengikut-pengikut ini biasa disebut joa' dan mereka berasal dari golongan tu maradeka (orang merdeka). (Ahimsa-Putra, 2018)

Masyarakat di Desa Marayoka bekerja sebagai petani, namun banyak dari mereka yang masih menggunakan lahan orang lain untuk digarap yang dikarenakan mereka (klien) kekurangan lahan untuk mencari nafkah dalam memenuhi kebutuhan demi kelangsungan hidupnya. Di Jeneponto terkenal dengan kakaraengannya sehinggah dahulu kebanyakan patron adalah karaeng, namun berbeda dengan halnya sekarang dimana kualitas seorang karaeng mulai di ragukan karena sering dijumpai mereka berbuat semena-mena pada rakyat kecil atau yang tidak beruang. Akan tetapi ketika kita jalan-jalan dikawasan Jeneponto maka akan banyak kita jumpai mereka yang memiliki gelar karaeng yang di wariskan dari turun temurun. Dari berbagai kalangan di Jeneponto panggilan karaeng tidak serta merta karena dia paling patut dihormati tetapi mereka mempunyai darah keturunan dari pemimping kita terdahulu. Dan bagi mereka uang adalah karaeng ketika tidak punya uang maka mereka bukan siapasiapa. (Paseway, 2018)
Patron adalah sebuah nama yang diberikan kepada seseorang yang dianggap kuat dan terpercaya dalam masyarakat Jeneponto. Adat istiadat yang dimiliki oleh seorang Karaeng sangat berbeda dengan bukan orang-orang yang termasuk dalam golongan karaeng. Dari segi derajat kemanusian yang dipahami, seorang karaeng adalah orang yang sangat dihargai dan dihormati oleh seorang masyarakat karena menganggap paling tinggi derajatnya khususnya didaerah Jeneponto dimasa dulu keluarga yang bergelar karaeng juga harus menikahkan anaknya dengan seorang keturunan anak karaeng. Ata (Klien) sekelompok masyarakat derajatnya sangat rendah di bandingkan dengan karaeng yang tidak memiliki sifat khusus yang dimiliki pada seorang karaeng pada khususnya. (Ervina, 2010)

Ciri-ciri patron klien Di Marayoka dengan ciri-ciri sebagai berikut: (1) Di Marayoka tentu memiliki strata sosial yang berbeda misalkan yang antara patron dan klien yang memiliki peran berbeda, tentu Di Marayoka tetap masih saling membutuhkan sebagai mahluk sosial. Yang hasil akhirnya tidak mengesampingkan dan mengecilkan rakyat-rakyat kecil dalam hal ini sebagai klien”. (2) Dalam kehidupan kita ini tentu masih saling membutuhkan satu sama lain, karena kita di ciptakan dengan nasib yang berbeda-beda, seperti halnya di Marayoka yang menjadi klien masa sekarang di masa mendatang mungkin mereka telah mengalami perkembangan ekonomi. Sala-satu contoh Dg Rurung di tahun 1960-1980 an berperang sebagai klien, namun setelah menikah takdir berkata lain dengan meningkatnya perekonomian sehingga mereka mampu mempekerjakan mereka-mereka yang berkekurangan dengan memberikan upah demi kelanjutan hidupnya" Dg Rurung juga dikenal sebagai orang yang selalu menaikkan upah hampir tiap tahun walaupun tidak seberapa banyak. Contoh dari upah 5.000 di naikkan menjadi 6.000 rupiah. (3) Berdasarkan penelitian Di 
Marayoka, masyarakat tidak hanya menggeluguti dibidang pertanian akan tetapi sekitaran $20 \%$ memilih terjung dalam bidang pedagangan. Sala-satunya berdagang jagung kuning biji. Dalam mempekerjakan buruh Dg Bollo sebagai patron di Marayoka tentunya memberikan upah dengan upah borongan, dalam satu mobil 500 ribu. Jadi buruhlah yang membagi hasil ketikan si buruh berjumlah 2 orang maka hasilnya 250/orang. Sering terjadi pemberian-pemberian dari sang patron baik itu secara Cuma-Cuma maupun utang untuk keberlangsungan hidup maka diberikan utang piutang dengan tidak dibebankan Bunga dengan perjanjian akan bekerja sampai utang seorang buruh lunas.

Adapun kajian relevan karya dari Ervina (skripsi) dengan judul "AjjoarengJoa: Hubungan Pemimpin dengan pengikutnya pada masyarakat bugisMakassar di Soppeng pada abad ke XX". 2010. Sedangkan peneliti membahas patron klien pada masyarakat Marayoka Jeneponto. Namun sama-sama membahas patron dan klien.

Adapun kajian relevan yang mengenai patron dan klien di Sulawesi selatan sebagai penunjang dalam penelitian ini, "Patron dan Klien di Sulawesi selatan”. salah-satu karya dari Heddy Srhi Ahimsa-Putra yang membahas tentang kondisi-kondisi sosial budaya masyarakat di Sulawesi Selatan khususnya pada masyarakat Bugis Makassar pada akhir abad ke 19, yang membuat Patron Klien tetap bertahan fungsionalnyastruktural buku ini telah memungkinkan penulis menepatkan gejala patronase dalam kontes yang lebih luas.

Adapun Jurnal sebagai penunjang penelitian ini yang membahas tentang Pergeseran Kelembagaan upah pada pertanian. Membahas pengupahan dalam pertanian yang sering disebut Kecurangan (Moral Hazar) maka mesti harus dilakukan atau dibangun sistem Patron-Klien yang melalui buruh langganan atau buruh tetap.

\section{B. Metode Penelitian}

Metode penelitian yang digunakan dalam penelitian ini adalah metode penelitian deskriptif. Penelitian yang bermaksud untuk membuat pencandraan (deskripsi) mengenai situasi-situasi atau kejadian-kejadian. Dalam arti penelitian deskriptif itu adalah akumulasi data dasar dalam cara deskriptif semata-mata tidak perlu mencari atau menerangkan saling berhubungan, mentest hipotesis, membuat ramalan, atau mendapatkan makna dan implikasi walaupun penelitian yang bertujuan untuk menemukan hal-hal tersebut dapat mencakup juga metodemetode deskriptif.

Dalam suatu penulisan karya ilmiah, terdapat cara yang di gunakan untuk menyusun karya ilmiah tersebut. Hal ini sering disebut sebagai metode. Metode berbeda dengan metodologi. Menurut Kenneth D. Bailey, metode adalah teknik penelitian atau alat yang di pergunakan untuk mengumpulkan data. (Abdul Rahman, 2018)

Penelitian ini bersifat deskriptif-analisis dengan menggunakan metode penelitian sejarah melalui tahap heuristik, kritik, interpretasi dan historiografi.

\section{Heuristik}

Pengumpulan sumber berkenaan dengan pengumpulan data dan informasi. Interpretasi berkenaan dengan pencairan dan keterkaitan makna antara fakta, sedangkan penulisan berkenaan dengan laporan hasil penelitian. (Kuntowijoyo, 2005)

Sumber sejarah dapat memiliki catatan, tradisi lisan, dan setiap titik atau secerca pun yang memberi penerangan bagi cerita kehidupan manusia terutama pada masyarakat tani di Marayoka. Metode observasi yaitu:

a. Pengamatan langsung kelapangan dimana peneliti dapat melakukan pengamatan langsung terhadap objek penelitian yakni di Marayoka. Adapun penulis dalam melakukan pengamatan langsung dilapangan dengan 
menggunakan bahan rekaman yang nantinya akan memberikan bukti atau rekaman

b. Metode wawancaranya dengan melakukan Tanya jawab dengan beberapa imporman terkait atau yang terlibat langsung dalam hal ini. Dimana orang yang paling berperang penting dalam perkembanagan dan kemajuan pertanian Marayoka yakni Dg Ngidi sebagai orang yang paling berpengaruh dan dituakan di tempat tersebut.

\section{Kritik}

Hasil dari penelitian sejarah yang akademis atau kritis memerlukan fakta-fakta yang telah teruji. Oleh karena itu data-data yang telah diperoleh melalui tahapan heuristik harus dikritik atau disaring sehingga diperoleh fakta-fakta yang subjektif mungkin kritik tersebut berupa kritik tentang otentitasnya (kritik ekstern) maupun kredebilitas isinya (kritik intern). (Sejarah, 2013)

\section{Interpretasi}

Interpretase merupakan tahapan selanjutnya setelah penulis melalui kritik sumber. Dimana sumber-sumber yang kita dapatkan perlu ditafsirkan oleh peneliti. Dan tahap interpretasi ini adalah tahap imajinasi sesorang peneliti di butuhkan untuk menafsirkan seluruh kejadian berdasarkan data-data yang terkumpul. Dalam proses penafsiran peneliti harus benar-benar berhati-hati sehinggah tidak terjebak dalam subjektifitas yang kadang kala sangat di pengaruhi oleh hasil penulisan

\section{Historiografi}

Tahap ini tahap yang terakhir pada metode sejarah. Setelah sumber di kumpulkan kemudian dikritik (seleksi) menjadi data kemudian dimaknai menjadi fakta, langkah terakhir adalah menyusun semuanya menjadi satu tulisan utuh yang berbentuk narasi kronologis.

Pada tahap ini penulis mencoba untuk menggambarkan hasil penelitiannya, dalam hal ini penulis berusaha meneliti patron- klien pada masyarakat tani di marayoka pada tahun 1970 sampai 2018.

\section{Tinjauan Lokasi penelitian}

Agar dapat memahami karakteristik Desa Maryoka pada lokasi penelitian maka pada bagian ini dapat diuraikan sebagai berikut:

Desa Marayoka merupakan salah satu desa/kelurahan di kec. Bangkala, kabupaten Jeneponto.yang mempunyai luas Wilayah $\pm 14,13 \mathrm{~km}^{3}$. desa ini merupakan hasil dari desa pallantikan bersama dengan desa marayoka pada tahun 1983 yang berbatasan dengan: Sebelah utara: berbatasan dengan desa Pappalluang dan desa Batu Rappe kab. Gowa. Sebelah Timur; Desa Bulu Sibatang kecamatan Bonto Ramba. Sebelah selatan: Desa Kapita. Sebelah barat: Gunung Silanu dan Kecamatan Bangkala Barat.

Dilihat dari letak geografisnya desa marayoka berada pada daerah dataran pengunungan dengan jarak dari kabupaten menuju ibukota kecamatan $25 \mathrm{~km}$ yang dapat ditempuhnya dalam jangka waktu \pm 60 menit dengan menumpangi kendaraan beroda dua (Ojek) sedangkan untuk ke ibu kota kabupaten yang berjarak $55 \mathrm{~km}$ dapat dijangkau dalam waktu 2 jam dengan menggunakan kendaraan beroda 2 tapi itupun harus keluar kecamatan karena angkutan umum berupa mobil yang tidak tersedia di desa.

\section{Pembahasan}

\section{Dasar-Dasar Hubungan Patron Klien Pada Masyarakat Tani Marayoka}

Kata "Petani" menimbulkan bayangan petani sederhana di pedesaan, orang-orang miskin yang hidup terpecil, terasing dari arus kegiatan pokok masyarakat. Peranan sektor pertanian dalam perekonomian nasional sangat penting dan strategis. Hal ini terutama karena sektor pertanian masih memberikan lapangan pekerjaan bagi 
sebagian besar penduduk yang ada dipedesaan dan menyediakan bahan pangan bagi penduduk. Peranan lain dari sektor pertanian adalah menyediakan bahan mentah bagi industri negara melalui ekspor non migas. Bahkan sektor pertanian mampu menjadi kutub pengaman perekonomian nasional dalam menhadapi krisis ekonomi yang melanda Indonesia. (Sadono, 2018) Ada beberapa faktor yang mendasari lahirnya ikatan patron-klien dalam masyarakat Bugis-Makassar.

Adanya sistem kekerabatan bilateral dimana sistem patronasi dalam batas tertentu merupakan kelompok kekerabatan yang teroganisir, seperti klan atau marga dalam masyarakat dengan sistem unilineal. Kelompok klien biasa diperkuat melalui perkawinan antar anggota, sehingga dalam waktu singkat sistem tersebut sulit dibedakan lagi dengan kelompok kekerabatan bilateral. menurut penuturan sala-satu mantan kades desa marayoka menyatakan bahwa:

"Di Marayoka pada tahun 1965-1975 belum mengenal sistem upah melainkan sukarela terhadap tuannya dengan alasan menghargai pemimpin dan beradat. seorang pemimpin jika memerlukan bantuan ia tidak perlu mengeluarkan upah selain memberi makan saja kepada pekerja sang klien, mereka yang dipekerjakan juga bukanlah orang lain melaingkan kerabat sendiri. Pada masa itu Marayoka memiliki KK kurang lebih dari 10 keluarga. Adapun dari kelurga sendiri tentunya tidak memberikan imbalan kepada mereka yang masih memiliki hubungan sedarah, melaingkan hanya membantu saja dengan catatan saling membantu dalam berbagai hal pekerjaan” (Tunru, 2019)

Kekerabatan merupakan unit-unit sosial yang terdiri atas beberapa keluarga yang mempunyai hubungan darah secara vertical maupun horizontal atau akibat dari perkawinan. Anggota dari sistem kekerabatan terdiri dari ayah, ibu, anak, cucu, kakak, adik, paman bibi, nenek, kakek, dan seterusnya. Kekerabatan juga dapat diartikan sebagai hubungan seseorang atau identitas yang sama secara sil-sila, keturunan, maupun adat yang sama. Kekerabatan adalah suatu unit terkecil dari masyarakat yang berasal dari dua keluarga, yakni keluarga inti dan keluarga besar.

Adanya suatu sistem stratifikasi sosial yang mengizinkan kaum bangsawan akan didukung orang banyak untuk menduduki jabatan politik juga merupakan dasar lahirnya sistem politik tersebut. Hubungan antara pemimpin dan pengikut, patron dan klien, terjalin secara sukarela dan hanya berdasarkan kontrak tak tertulis:

"Bercerita mengenai kondisi masyarakat marayoka Pada tahun 19611967 sebelum dipugar menjadi sebuah desa, marayoka masih dalam kondisi belum stabil dimana mereka masih saling menyerang satu sama lain sehingga setiap rumpung keluarga mencari tempat yang nyaman dan pindah ke kampung yang lama atau biasa disebut "angnyingkirr" dari kampung baru ke yang lama demi keselamatan dan membuka lahan baru kembali.” (Haban, 2019)

Petani hidup dalam suatu sistem budaya, mereka-mereka punya hubungan sosial yang perlu di rawat melalui kegiatan upacara tertentu misalnya pesta perkawinan, pesta kematian. Artinya dari produksi yang dihasilkan harus juga siap aggaran untuk (tabungan upacara) dengan dengan cara seperti ini, para petani dapat hidup ditengah masyarakat.

Penjelasan diatas merupakan elemen penting dalam proses produksi keluarga petani. Tapi petani juga dalam hubungan yang dijajah oleh kelas-kelas non produsen (tuan tanah, bangsawan, pemerintah dan sebagainya). Perlu diingat bahwa sebagian dari apa yang dihasilkan oleh petani juga di ubah sebagai "sewa" yakni keuntungan yang didapat dari petani 
penhasil kepada kelas non produsen. (Fararuk, 1992)

Adapun fungsi dari kelompok tani yakni: penyuluhan pembambangunan yang ditunjukkan lewat media komunikasi kelompok akan dapat mempercepat proses penyadaran masyarakat tentang beragam proses pembangunan. Berdasarkan tabel data kelembagaan petani atau kelompok tani mulai pembentukan kelompok tani dari tahun 2012 hingga sekarang. Dengan pembentukan kelompok tani akan memperlancar jalannya kersama dalam pertanian.

\section{Pola Hubungan Patron-Klien pada masyarakat di Marayoka}

Christian Pelras mengatakan hubungan patron-klien merupakan hubungan yang tidak setara yang terjaling secara perorangan antara seorang pemuka masyarakat (patron) dengan sejumlah pengikutnya (klien). Hubungan itu berdasarkan pertukaran jasa, dimana ketergantungan klien pada patron diimbali oleh perlindungan patron pada kliennya.

"tahun 1960-1970-an, tenaga buruh di hargai kisaran 300-400 rupiah/perhari saat ia masih mudah (belum menikah) pada tahun 1980-1990-an (setelah menikah) ia sudah mulai melakukan kerja borongan pembajakan sawah secara kelompok dengan masih menggunakan tenaga kerbau lalu pada tahun selanjutnya berganti dengan menggunakan tenaga jasa sapi sebelum hadirnya traktor didesa kami”. (Rurung, 2019)

Kemudian James Scoott mengatakan hubungan patron-klien merupakan hubungan special antar dua pihak dimana pihak yang memiliki status ekonomi yang lebih tinggi menggunakan pengaruhnya dan resourcesnya untuk melindungi dan memberi manfaat pada pihak status sosial yang ekonominya lebih rendah. (Ng Aini Philipus, 2004)

Peter M. Blau mengatakan hubungan patron klien lebih merupakan hubungan pertukaran (exchange relationship) bahwa: a) Pertukaran hanya terjadi diantara pelaku yang mengharapkan imbalan dari pelaku lain dalam hubungan mereka

b) Dalam mengejar imbalan ini, para pelaku dikonseptualisasikan sebagai seorang yang mengejar profit.

c) Pertukaran antara dua macam, yang langsung (dalam jaringan interaksi yang relatif kecil) dan kurang langsung (dalam sistem sosial yang lebih besar)

d) Ada 4 imbalan dengan derajat berbeda yaitu uang, persetujuan sosial, penghormatan/penghargaan dan kepatuhan.

Berdasarkan teori diatas dapat disimpulkan bahwa (1) "berdasarkan tempat penelitian, Di Marayoka masuk dalam hal tersebut misalkan sang patron mempekerjakan klien sebagai buruh tani terikat, maka klien ini biasanya menambah tenaga buruh untuk pekerjaan patronnnya, maka skilen ini masuk dalam sistem sambata saling membantu dengan upah klien sendiri yang mendapatkan keuntungan” (2) "nah, di Marayoka dalam hal ini dapat diartikan dengan buruh bangun hanya dijadikan sebagai gaji tambahan sembari menunggu hasil panen dari pertanian. Biasa dalam pengerjaan proyek misalnya dalam jangka 2 bulan harus selesai proyek tersebut, patron (bos) dalam hal ini yang mengukur dan mengatur bagaimana bentuk proses penyelasaian proyek tersebut dalam jangka waktu 2 bulan. (3) "Pada umumnya, hubungan sosial terdiri dari pada masyarakat, maka kita dan masyarakat lain mempunya perilaku yang saling mempengaruhi dalam hubungan tersebut, yang terdapat unsur ganjaran, pengorbanan dan keuntungan” (4) sebelum menyetujui suatu perkara maka sebelum itu tentu terlebih dahulu melakukan interaksi secara langsung sehingga hasil akhir tidak membuat kesalahan.

Yang dimaksud dengan pola hubungan adalah apakah petani berada dalam lingkup pola hubungan kosmopolitas atau lokalitas. Biasanya petani yang berada 
dalam pola hubungan yang kosmopolitas, kebanyakan dari mereka lebih cepat melakukan adopsi inovasi. Begitupun sebaliknya bagi petani yang berada dalam lingkungan pola hubungan yang bersifat lokalitas. (Soekartawi, 1988)

a. Relasi petani dengan buruh tani bebas

Ditandai dengan adanya relasi ketetanggaan dan bahkan hanya relasi kerja atau pertukaran sosial atau hubungan transaksi dipasar tenaga kerja saja. Seperti halnya di Marayoka pekerja sehari yang diberikan langsung upahnya setelah pekerjaannya selesai. Sesau dengan perjanjian berbeda dengan buruh tetap yang bahkan selalu ada untuk mengerjakan pekerjaan tuannya susah untuk berpindah

b. Relasi petani dengan buruh tani langganan

Ditandai dengan adanya hubungan kekerabatan, persaudaraan, kekeluargaan dan lainnya. Banyak petani yang asil bersihnya (setelah dipotong sewa dan biaya produksi) dibawa subsistensi, pekerjaanpekerjaan sampingan itu sudah merupakan bagian yang lazim dan tidak terpisahkan dari subsistansial secara keseluruhan.

c. Relasi petani dengan buruh tani tetap

Ditandai dengan adanya relasi patronase yakni hubungan yang lebih rumit. Relasi patronase yang terbentuk bervariasi tergantung kompleksitas hubungan yang telah terjadi dan perbedaan sosial budaya yang melatar belakanginya. (Astuti, 2012)

\section{E. Kesimpulan}

Hubungan antara pemimpin dan pengikut di Marayoka pada tahun 1970 terjalin secara sukarela dan hanya berdasarkan kontrak tak tertulis. Hubungan ini berakhir kapan saja dan sepanjang klien tidak memiliki hutang kepada patronnya maka dia setiap saat dapat pindah kepatron lain. Sama halnya dengan hubungan tuan tanah dengan buruh tani yang tidak terikat dan tidak memiliki hutang maka ia bebas pindah patron kapan saja tergantung bagaimana bisa menghidupi kebutuhan sehari-hari
Hubungan kerja pada masyarakat pertanian antara petani pemilik dan buruh tani Marayoka terdapat unsur hubungan kekeluaargaan atau kekerabatan. Dalam hubungan masyarakat industri hanya berkisar pada hubungan ekonomi. Sistem pengupahan dalam masyarakat pertanian lebih condong pada pola kegotongroyongan dalam bertani

\section{DAFTAR PUSTAKA}

Abdul Rahman, M. M. S., 2018. Pengantar Ilmu Sejarah. Makassar: Rayhan Intermedia.

Ahimsa-Putra, H. S., 2018. Patron dan Klien di Sulawesi Selatan. Yogyakarta: Kepel Press.

Astuti, S., 2012. Pola Relasi Sosial Petani dengan Buruh Tani dalam Produksi Pertanian, Medan: Universitas Sumatra Utara.

Ervina, 2010. A"joareng-Joa: Hubungan Penguasa dengan Rakyat pada Abad ke $X X$, Makassar: Fakultas Ilmu Sosial UNM.

Fararuk, Y., 1992. Petani Kopi Rindingallo, Ujung Pandang: Fakultas Sastra Unhas.

Haban, 2019. Wawancara [Interview] (10 Juli 2019).

Kuntowijoyo, 2005. Pengantar Ilmu Sejarah. Yogyakarta: Bentang.

Ng Aini Philipus, N., 2004. Sosiologi dan Politik. Jakarta: Raja Grafindo Persada.

Paseway, P., 2018. wawancara [Interview] (1 November 2018).

Rurung, D., 2019. Wawancacra [Interview] (10 Juli 2019).

Sadono, D., 2018. Pemberdayaan Petani Paradigma Baru Penyuluhan Pertanian di Indonesia. Jurnal Penyuluhan, Volume 4, p. 65.

Sejarah, T. P. J. P., 2013. Pengantar Ilmu Sejarah. Makassar: Balai Penerbit UNM. 
Soekartawi, 1988. Prinsip Dasar Komunikasi Pertanian. Jakarta: Universitas Indonesia.

Tunru, 2019. Wawancara [Interview] (9 Juli 2019). 